\title{
Article \\ Genome Characterization of Bird-Related Rhabdoviruses Circulating in Africa
}

\author{
Dong-Sheng Luo ${ }^{1,2,3}$, Zhi-Jian Zhou ${ }^{4}$, Xing-Yi Ge ${ }^{4} \mathbb{D}$, Hervé Bourhy ${ }^{3}$, Zheng-Li Shi ${ }^{1,2} \mathbb{D}$, Marc Grandadam $^{5,6}$ \\ and Laurent Dacheux ${ }^{3, *(1)}$
}

1 CAS Key Laboratory of Special Pathogens and Biosafety, Wuhan Institute of Virology, Chinese Academy of Sciences, Wuhan 430071, China; dongshengluo@outlook.com (D.-S.L.); zlshi@wh.iov.cn (Z.-L.S.)

2 University of Chinese Academy of Sciences, Beijing 100049, China

3 Lyssavirus Epidemiology and Neuropathology Unit, Institut Pasteur, Université de Paris, 75015 Paris, France; herve.bourhy@pasteur.fr

4 Hunan Provincial Key Laboratory of Medical Virology, College of Biology, Hunan University, Changsha 410082, China; zjzhou@hnu.edu.cn (Z.-J.Z.); xyge@hnu.edu.cn (X.-Y.G.)

5 Institut de Recherche Biomédicale des Armées, 91220 Bretigny-sur-Orge, France; marc.grandadam@orange.fr

6 National Reference Center for Arboviruses, Institut Pasteur, Université de Paris, 75015 Paris, France

* Correspondence: laurent.dacheux@pasteur.fr; Tel.: +33-140613303

check for updates

Citation: Luo, D.-S.; Zhou, Z.-J.; Ge, X.-Y.; Bourhy, H.; Shi, Z.-L.;

Grandadam, M.; Dacheux, L. Genome Characterization of Bird-Related Rhabdoviruses Circulating in Africa. Viruses 2021, 13, 2168. https:/ / doi.org/10.3390/v13112168

Academic Editor: Tae-Jin Choi

Received: 25 September 2021

Accepted: 22 October 2021

Published: 27 October 2021

Publisher's Note: MDPI stays neutral with regard to jurisdictional claims in published maps and institutional affiliations.

Copyright: (c) 2021 by the authors. Licensee MDPI, Basel, Switzerland. This article is an open access article distributed under the terms and conditions of the Creative Commons Attribution (CC BY) license (https:// creativecommons.org/licenses/by/ $4.0 /)$.

\begin{abstract}
Rhabdoviridae is the most diverse family of the negative, single-stranded RNA viruses, which includes 40 ecologically different genera that infect plants, insects, reptiles, fishes, and mammals, including humans, and birds. To date, only a few bird-related rhabdoviruses among the genera Sunrhavirus, Hapavirus, and Tupavirus have been described and analyzed at the molecular level. In this study, we characterized seven additional and previously unclassified rhabdoviruses, which were isolated from various bird species collected in Africa during the 1960s and 1970s. Based on the analysis of their genome sequences obtained by next generation sequencing, we observed a classical genomic structure, with the presence of the five canonical rhabdovirus genes, i.e., nucleoprotein $(\mathrm{N})$, phosphoprotein $(\mathrm{P})$, matrix protein $(\mathrm{M})$, glycoprotein $(\mathrm{G})$, and polymerase $(\mathrm{L})$. In addition, different additional open reading frames which code putative proteins of unknown function were identified, with the common presence of the $\mathrm{C}$ and the $\mathrm{SH}$ proteins, within the $\mathrm{P}$ gene and between the $\mathrm{M}$ and $G$ genes, respectively. Genetic comparisons and phylogenetic analysis demonstrated that these seven bird-related rhabdoviruses could be considered as putative new species within the genus Sunrhavirus, where they clustered into a single group (named Clade III), a companion to two other groups that encompass mainly insect-related viruses. The results of this study shed light on the high diversity of the rhabdoviruses circulating in birds, mainly in Africa. Their close relationship with other insect-related sunrhaviruses raise questions about their potential role and impact as arboviruses that affect bird communities.
\end{abstract}

Keywords: rhabdovirus; Sunrhavirus; bird; genome; Africa; NGS; genetic diversity; arbovirus

\section{Introduction}

Rhabdoviruses are enveloped RNA viruses belonging to the order Mononegavirales. They are characterized by a bullet or rod shape and contain a single or segmented molecule of linear negative-strand RNA of a size approximately $10-16 \mathrm{~kb}$, which contains the five canonical genes encoding the nucleoprotein $(\mathrm{N})$, the phosphoprotein $(\mathrm{P})$, the matrix protein $(\mathrm{M})$, the glycoprotein $(\mathrm{G})$, and the RNA-dependent RNA polymerase (L) [1,2]. Moreover, various novel and diverse accessory genes or putative open reading frames (ORFs) overlap these genes or are interspersed between them [3]. Each gene and some of the accessory ORFs are flanked by relatively well-conserved transcription initiation (TI) and transcription termination polyadenylation (TTP) sequences [1,3]. 
The family Rhabdoviridae is the most diverse within the Mononegavirales, with 40 different genera and 246 species according to the latest update by the International Committee on Taxonomy of Viruses (ICTV: https: / / talk.ictvonline.org/, accessed on 25 September 2021) [2]. The members of this family exhibit a large ecological diversity, with pathogens infecting various plants or animals, including mammals, such as livestock and humans, insects, fishes, reptiles, and birds. Some of them have significant public health, livestock, aquaculture, and agricultural impacts [4]. However, dozens of putative or unclassified new species are waiting to be assigned to potential new genera in the near future. Early taxonomy of these viruses was based on virion morphology and serological cross-reactivity. Thus, many unclassified rhabdoviruses had been assigned to certain taxa, according to serological cross-reactivity with some typical members of the same rhabdovirus genus or group. For instance, Tupaia virus (TUPV) and Klamath virus (KLAV) had been related to Vesiculovirus genus [5-7], but subsequent molecular analysis definitively classified them into the new and distinct Tupavirus genus [1]. Similarly, the previously uncharacterized Duvenhage lyssavirus (DUVV), Lagos bat lyssavirus (LBV), Mokola lyssavirus (MOKV), European bat lyssavirus 1 (EBLV-1), and European bat lyssavirus 2 (EBLV-2) were initially classified into rabies-related viruses by serological test before being considered as individual species among the genus Lyssavirus [8]. As the development of molecular and sequencing techniques have become more and more efficient and available, genotyping is now considered to be a key element in viral taxonomy $[9,10]$.

Until now, 12 bird-related viruses were encompassed within the family Rhabdoviridae, in three different genera, namely Tupavirus, Hapavirus, and Sunrhavirus. Most of them were identified in different bird species in Africa, with the exception of Durham virus (DURV), which was isolated from Fulica americana in North America in 2005 [11]. This virus is the only bird-related rhabdovirus within the Tupavirus genus. Similarly, Landjia hapavirus (LJAV), isolated from Riparia paludicola in the Central African Republic in 1970, is the unique representative of bird-related viruses among the Hapavirus genus [1]. Conversely, the new taxonomic genus Sunrhavirus is associated to a significant degree with birds, and includes Sunguru virus (SUNV), which is described in domestic chicken in Uganda in 2013 [12], Garba virus (GARV), which is reported in Corythornis cristata in Bangui in the Central African Republic in 1970 [1], as well as the unclassified rhabdovirus, Farmington virus (FARV), also identified in wild bird in North America in 1969 [13].

In addition to these characterized viruses, other bird rhabdoviruses are still waiting for taxonomic assignation, and include five viruses collected in the Central African Republic with the Bimbo (BBOV), Kolongo (KOLV), Nasoule (NASV), Ouango (OUAV), and Sandjimba (SAJV) viruses, and two rhabdoviruses collected in Egypt called the Matariya (MTYV) and Burg el Arab (BEAV) viruses. At the time of their collection, initial serological analysis evidenced links to rabies virus groups or bovine ephemeral fever ephemerovirus groups $[5,14,15]$. Subsequent studies based on a phylogenetic analysis of limited regions among the $\mathrm{N}$ and $\mathrm{L}$ genes repositioned them into the unclassified Sandjimba group [16-19]. Later, the members of the Sandjimba group, which were most closely related to several bird- or insect-associated rhabdoviruses which originated in America and Africa, were assigned to the new rhabdoviruses genus Sunrhavirus [1,12,14,16-19].

In this study, we extended the knowledge on bird-related rhabdoviruses and their associated genetic diversity through the molecular characterization of the nearly complete genome of these seven unclassified virus species, all of them isolated between 1960s to 1970s in wild birds circulating in Africa. Based on molecular analysis conducted on their genome sequences that were obtained by next generation sequencing (NGS), we confirmed that they belonged to the genus Sunrhavirus, sharing a common genomic organization and sequence similarities. Our results demonstrated that these seven bird-related rhabdoviruses could represent putative individual new species which are phylogenetically clustered into a single group within the genus Sunrhavirus. These data demonstrate that there is a high level of genetic diversity in the rhabdoviruses that are potentially circulating in African birds. Their close relationship with other insect-related sunrhaviruses, as well as the fact 
that most of them were isolated from the blood of infected birds, raises questions as to whether they are arthropod-borne and could affect bird communities.

\section{Materials and Methods}

\subsection{Virus Description}

All of the viruses characterized in this study were isolated from wild birds in Africa during large field campaigns that were carried out in the 1960s and the 1970s to collect samples of wildlife, with the main aim of evaluating the presence of arboviruses, in particular by virus isolation and serology characterization. Five of them were collected in the Central African Republic, including Bimbo virus (BBOV, isolate AnB1054d or 9716RCA), Kolongo virus (KOLV, isolate AnB1094d or 9717RCA), Ouango virus (OUAV, isolate AnB1582a or 9718RCA), Sandjimba virus (SAJV, isolate AnB373 or 0408RCA), and Nasoule virus (NASV, isolate AnB4289a or 0410RCA), whereas Matariya virus (MTYV, isolate EgAn1477-61 or 09027EGY) and Burg el Arab virus (BEAV, isolate An3782-62 or 09023EGY) were collected in Egypt $[5,15]$. All of these samples were collected with nets in various types of landscapes (such as mosaic savanna forests, equatorial humid forests, oases in semi-deserts, or urban/semi-urban areas). The complete description of these viruses is presented in Table 1. Briefly, BBOV and KOLV were obtained from a pool of crushed organs (heart, brain, and spleen) of Euplectes afer that were collected in 1970 in the suburb of Bangui city. OUAV and SAJV originated from Landjia city in 1970, and were collected from the blood of Sitagra melanocephalus and a pool of crushed organs (heart, brain, spleen, and liver) from Acrocephalus schoenobaenus, respectively. NASV was isolated from the blood of Eurillas virens (Andropadus virens) that were collected in 1970 in Nasoulé city. Lastly, both Egyptian Matariya virus (09023EGY) and Burg el Arab virus (09027EGY) were obtained from the blood of Sylvia curraca sampled in Port Saïd in 1961 and in Bahig in 1962, respectively. At the time, all these viruses were isolated, amplified after the intra-cerebral (and sometime intra-peritoneal) inoculation of suckling newborn mice, and stored long term at $-80^{\circ} \mathrm{C}$ after freeze-drying. The initial characterization of these viruses was performed serologically, using complement fixation, and immunofluorescent and plaque reduction neutralization assays with reference sera panels, leading to classification by serogroup $[5,20]$.

Table 1. Description of the bird rhabdoviruses characterized in this study.

\begin{tabular}{|c|c|c|c|c|c|c|c|c|}
\hline Isolate & Name & Acronym & City & Country & Date of Collection & Host Species & $\begin{array}{l}\text { Original } \\
\text { Samples }\end{array}$ & $\begin{array}{c}\text { Tested } \\
\text { Samples }\end{array}$ \\
\hline 9716RCA & Bimbo virus & BBOV & Kolongo & $\begin{array}{c}\text { Central African } \\
\text { Republic }\end{array}$ & 18 July 1970 & Euplectes afra & Unknown & Mouse brain \\
\hline 9717RCA & Kolongo virus & KOLV & Bangui & $\begin{array}{c}\text { Central African } \\
\text { Republic }\end{array}$ & 18 July 1970 & Euplectes afra & $\begin{array}{l}\text { Pool of } \\
\text { crushed } \\
\text { organs }\end{array}$ & Mouse brain \\
\hline 9718RCA & Ouango virus & OUAV & Landjia & $\begin{array}{c}\text { Central African } \\
\text { Republic }\end{array}$ & 10 October 1970 & $\begin{array}{c}\text { Ploceus } \\
\text { melanocephalus }\end{array}$ & Blood & Mouse brain \\
\hline 0408RCA & $\begin{array}{l}\text { Sandjimba } \\
\text { virus }\end{array}$ & SJAV & Landjia & $\begin{array}{c}\text { Central African } \\
\text { Republic }\end{array}$ & 21 January 1970 & $\begin{array}{c}\text { Acrocephalus } \\
\text { schoenbaeus }\end{array}$ & $\begin{array}{l}\text { Pool of } \\
\text { crushed } \\
\text { organs }\end{array}$ & Mouse brain \\
\hline 0410RCA & Nasoule virus & NASV & Nasoulé & $\begin{array}{c}\text { Central African } \\
\text { Republic }\end{array}$ & 15 September 1973 & $\begin{array}{c}\text { Andropadus } \\
\text { virens }\end{array}$ & Blood & Mouse brain \\
\hline 09023EGY & $\begin{array}{c}\text { Burg el } \\
\text { Arab virus }\end{array}$ & BEAV & Bahig & Egypt & 15 October 1962 & Sylvia curraca & Unknown & Mouse brain \\
\hline 09027EGY & Matariya virus & MTYV & Port Saïd & Egypt & 8 October 1961 & Sylvia curraca & Unknown & Mouse brain \\
\hline
\end{tabular}




\subsection{RNA Extraction}

Total RNA extraction was performed using Direct-zol ${ }^{\mathrm{TM}}$ RNA MiniPrep kit (Zymo Research, Irvine, CA, USA) following the manufacturer's instructions. Briefly, $600 \mu \mathrm{L}$ of TRIzol reagent (Invitrogen, llkirch-Graffenstaden, France) was added to nearly $200 \mu \mathrm{L}$ resuspended lyophilized suckling mice brain in nuclease-free water. A DNase I digestion step was performed on-column, according to the manufacturer's recommendations. Total RNA extraction was eluted in $50 \mu \mathrm{L}$ nuclease free and stored at $-80^{\circ} \mathrm{C}$ for further analysis.

\subsection{Genome Sequence Determination}

Genome sequences of the bird-related rhabdovirus were obtained using next generation sequencing (NGS) as previously described [21-23]. A ribosomal RNA depletion step was first carried out with $2-4 \mu \mathrm{g}$ of RNA with $1 \mu \mathrm{L}$ of Terminator $5^{\prime}$-Phosphate-Dependent Exonuclease (Epicentre Biotechnologies, Madison, WI, USA), in addition to $2 \mu \mathrm{L}$ of buffer A and $0.5 \mu \mathrm{L}$ of RNAsin Ribonuclease inhibitor (Promega, Charbonnières-les-Bains, France). After being adjusted to $20 \mu \mathrm{L}$ with nuclease-free water, the mix was incubated for $1 \mathrm{~h}$ at $30{ }^{\circ} \mathrm{C}$. The depleted RNA was then purified using Agencourt RNAclean XP beads (Beckman Coulter, Villepinte, France) at a ratio of 1:1.8, following the manufacturer's instructions. Purified RNA was then reverse transcribed in complementary DNA (cDNA) using the Superscript III reverse transcriptase (Invitrogen) according to the manufacturer's instructions. For this step, $8 \mu \mathrm{L}$ of RNA was first incubated at $70^{\circ} \mathrm{C}$ for 5 min with $1 \mu \mathrm{L}$ of $10 \mathrm{mM}$ dNTP mix (Invitrogen) and $1 \mu \mathrm{L}$ of $50 \mu \mathrm{M}$ of random hexamers (Invitrogen), then placed on ice. The complementary step was performed with the addition of $1 \mu \mathrm{L}$ (200 U) of Superscript III Reverse transcriptase (Invitrogen), $2 \mu \mathrm{L}$ of $10 \times$ First-Strand Reaction Buffer, $2 \mu \mathrm{L}$ of $0.1 \mathrm{DTT}, 4 \mu \mathrm{L}$ of $25 \mathrm{mM} \mathrm{MgCl}_{2}$, and $1 \mu \mathrm{L}$ of RNAsin Ribonuclease inhibitor (Promega) for a final volume of $20 \mu \mathrm{L}$. The mix was incubated at $25^{\circ} \mathrm{C}$ for $10 \mathrm{~min}$ then at $50{ }^{\circ} \mathrm{C}$ for $90 \mathrm{~min}$. Afterward, double-stranded DNA (dsDNA) was synthesized in a reaction mix containing $20 \mu \mathrm{L}$ of fresh cDNA, $10 \times$ Second-Strand Synthesis Reaction Buffer (New England Biolabs, Evry, France), $3 \mu \mathrm{L}$ of $10 \mathrm{mM}$ dNTP mix (Invitrogen), $1 \mu \mathrm{L}$ (10 U) of E. coli DNA ligase (New England Biolabs), $4 \mu \mathrm{L}(40 \mathrm{U})$ of E. coli DNA polymerase I (New England Biolabs), $1 \mu \mathrm{L}$ (5 U) of E. coli RNase H (New England Biolabs), and $43 \mu \mathrm{L}$ of nuclease-free water, after incubation at $16^{\circ} \mathrm{C}$ for $2 \mathrm{~h}$. The total volume $(80 \mu \mathrm{L})$ of dsDNA was finally purified for each virus, using a ratio of 1:1.8 of AMPure XP beads (Beckman Coulter) following the manufacturer's instructions. Finally, dsDNA libraries were constructed using the Nextera XT kit (Illumina, Evry, France) and sequenced using a $2 \times 150$ nucleotide paired-end strategy on the NextSeq500 platform as previously described [21-23].

The NGS data were analyzed using de novo assembly and mapping (both using CLC Assembly Cell, Qiagen, Hilden, Germany) with a dedicated workflow built on the Galaxy platform of Institut Pasteur [21-24]. Contig sequences were assembled and manually edited to produce the final consensus genome using Sequencher 5.2.4 (Gene Codes Corporation, Ann Arbor, MI, USA). The quality and the accuracy of the final genome sequences were checked after a final mapping step of the original cleaned reads and visualized using Tablet [25].

In case of low covering regions or the presence of gaps, different primer datasets were designed, based either on the sequences obtained by NGS (specific primers) or on the most closely related sequences available in GenBank (Supplementary Materials, Table S1). These primers were used by conventional PCR (nested or not) using TaKaRa EX Taq (TaKaRa, Kusatsu City, Japan) according to the manufacturer's instructions, and the amplicons were submitted for Sanger sequencing to fulfil the gaps present in the genome sequences.

Complete genome sequences were deposited in GenBank under the accession numbers MW491754-MW491760. 


\subsection{Sequences Analysis}

Identification of putative additional ORFs ( $\geq 180 \mathrm{nt})$ were performed with Sequencher 5.2.4. The presence of accessory genes was evaluated after comparison with similar genome regions of other rhabdoviruses belonging to the same genus which were available in GenBank.

Phylogenetic analysis of the bird-related viruses and other rhabdoviruses was conducted using datasets of reference sequences downloaded from GenBank (Supplementary Materials, Table S2). Two datasets were used, with the first one including the complete amino acid sequences of the polymerase of 229 other rhabdovirus representatives, whereas the second one encompassed the concatenated nucleotide sequences of the canonical genes $(\mathrm{N}, \mathrm{P}, \mathrm{M}, \mathrm{G}$, and $\mathrm{L})$ of the different sunrhaviruses (14, including the seven new sequences). All these sequences were aligned using ClustalW (version 2.0) [26] or Clustal Omega (version 1.2.4, implemented in SnapGene version 5.3.2) [27], and checked manually for accuracy. Phylogenetic trees were then constructed with IQ-TREE (version 1.6.10) [28] or PhyML (version 3.0) [29], using Maximum Likelihood models with 1000 bootstrap. Sequence identities of were performed using MEGA (version 7.0) [30]. Protein analyses were performed using SnapGene software (version 5.2.3) for predicted molecular weights (MW), isoelectric points (pI), and charge values (at $\mathrm{pH} 7)$, using the ProtParam tool on the ExPASy server (https:/ / www.expasy.org/resources/protparam, accessed on 22 September 2021) [31] for the calculation of instability, aliphatic, and grand average of hydropathicity (GRAVY), using TMHMM Server (version 2.0) (http: //www.cbs.dtu.dk/services/TMHMM-2.0/, accessed on 22 September 2021) and TMpred server on the ExPASy server to identify transmembrane helices, and using the normal prediction on Phoebius server (https://phobius.sbc.su.se/index.html, accessed on 22 September 2021) [32] to determine the putative protein topology.

\section{Results}

\subsection{Genome Characterization of the Bird-Related Rhabdoviruses}

The determination of the genome sequences of the seven bird-related rhabdoviruses was performed using NGS. Between 0.1 to 12 million raw reads were obtained per sample (around 6 million reads on average) (Table 2). Any remaining gaps and low coverage regions were resolved through specific PCR or nested-PCR and Sanger sequencing of the corresponding amplicons. Each final consensus sequence was then used as a reference sequence for a last mapping round for final verification (Table 2). Nearly complete genome sequences (without the $3^{\prime}$ leader and $5^{\prime}$ trailer sequences) were obtained for all of the seven viruses, which ranged from 10,805 to 11,021 nt in length. The average coverage for each sequence varied from 10x to 600x (Table 2, and Supplementary Materials, Figure S1).

Table 2. NGS results obtained for the genome sequences of the seven bird-related rhabdovirus.

\begin{tabular}{cccccccc}
\hline Isolate & Virus & $\begin{array}{c}\text { Genome } \\
\text { Size (nt) }\end{array}$ & $\begin{array}{c}\text { Raw Reads } \\
\text { (no) }\end{array}$ & $\begin{array}{c}\text { Reads } \\
\text { Cleaned } \\
\text { (no) }\end{array}$ & $\begin{array}{c}\text { Mapped } \\
\text { Reads } \\
\text { (no) }\end{array}$ & $\begin{array}{c}\text { Average Coverage } \\
\text { Depth * (x) }\end{array}$ & $\begin{array}{c}\text { GenBank } \\
\text { Accession } \\
\text { Number }\end{array}$ \\
\hline 9716RCA & BBOV & 10,969 & $3,547,036$ & $3,013,558$ & 15,226 & 206.23 & MW491756 \\
9717RCA & KOLV & 10,971 & $4,881,362$ & $4,214,012$ & 46,475 & 629.49 & MW491757 \\
9718RCA & OUAV & 10,805 & $12,256,546$ & $9,754,242$ & 28,150 & 384.67 & MW491758 \\
0408RCA & SJAV & 10,951 & $12,164,616$ & $9,908,488$ & 14,166 & 191.80 & MW491754 \\
0410RCA & NASV & 10,977 & $8,689,566$ & $6,630,310$ & 20,937 & 281.01 & MW491755 \\
09023EGY & BEAV & 10,846 & 101,186 & 65,258 & 832 & 11.15 & MW491759 \\
09027EGY & MTYV & 11,021 & $2,742,712$ & $2,289,168$ & 3635 & 45.58 & MW491760 \\
\hline
\end{tabular}

* Sequence coverage obtained after the last mapping round. 
All of the seven bird-related viruses exhibited a typical rhabdovirus genome organization, with the five canonical genes which encode, in the following order, the $\mathrm{N}$ (1257-1284 nt, $418-427$ aa), P (759-852 nt, 252-283 aa), M (498-522 nt, 165-173 aa), G (1644-1698 nt, $547-565 \mathrm{aa})$, and the L (6201-6219 nt, 2066-2072 aa) proteins (Figure 1). Numerous putative accessory genes $(\mathrm{U})$ which present additional ORFs were also identified among the genome sequences, from two (with NASV, OUAV, and MTYV) to seven (with BBOV) (Figure 1).

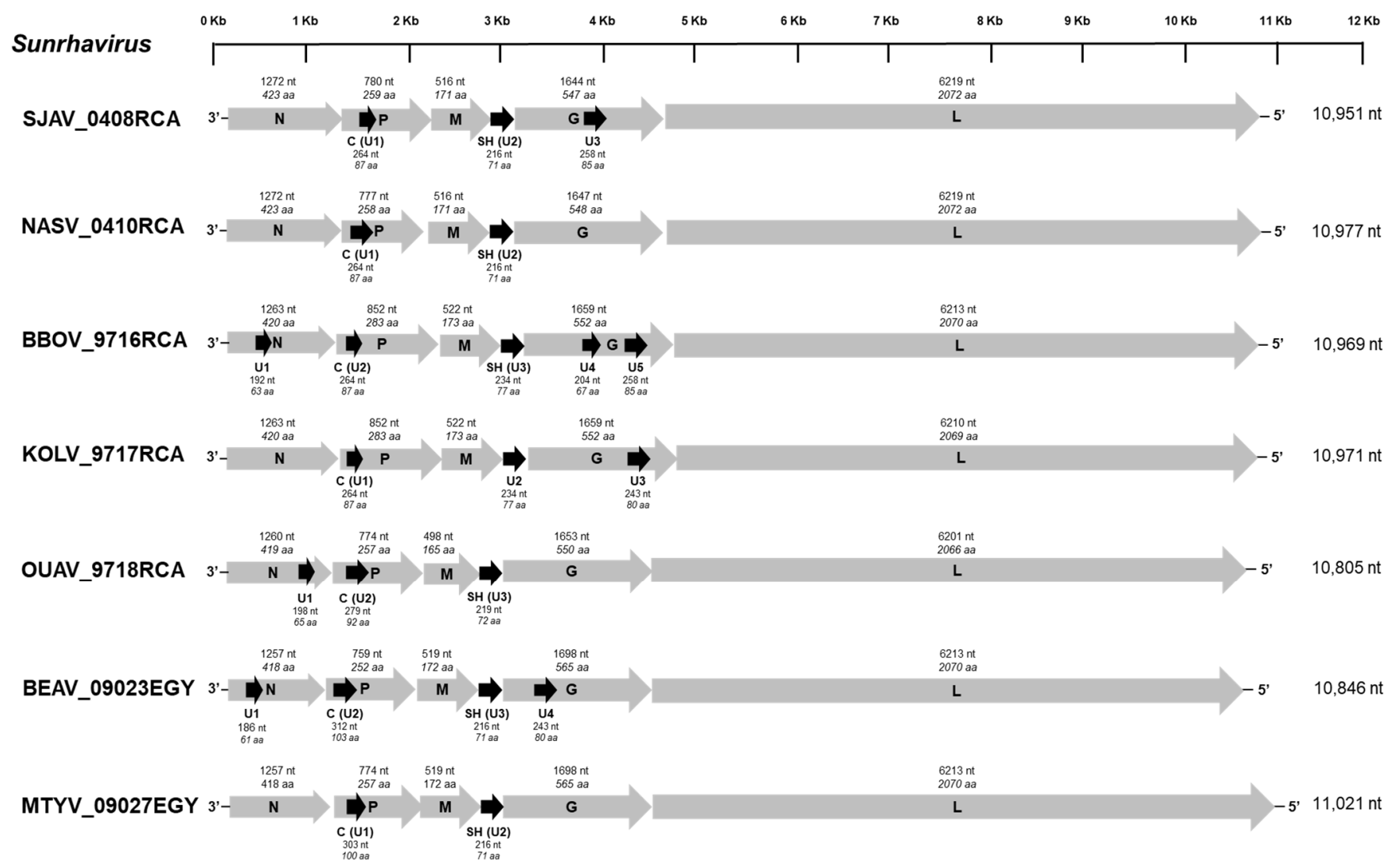

Figure 1. Schematic genome organization of the seven bird-related sunrhaviruses. The gray and black arrows represent the five canonical open reading frames (ORFs) (N, P, M, G, and L), and the putative additional ORFs ( $\geq 180 \mathrm{nt}$ ), respectively. The length (nucleotide and amino acid) of each ORF is indicated.

Each of these viruses presented a putative alternative ORF within the P gene (264-312 nt, 87-103 aa), which corresponds to the $C$ protein already found in other rhabdoviruses, such as Sunguru virus (SUNV), Garba virus (GARV), Durham virus (DURV), Tupaia virus (TUPV), or Klamath virus (KLAV). This protein exhibited a variable spectrum of amino acid conservation among the seven newly described bird-related viruses, including GARV (identity $26.1-80.4 \%$ ), or after comparison with the three other sunrhaviruses, namely SUNV, Harrison Dam (HDV), and Walkabout Creek (WCB) viruses (10.6-28.7\%), and they were highly distinct from the other sunrhaviruses and tupaviruses (Supplementary Materials, Figure S2 and Table S3A). For all of the seven bird-related viruses, this protein was predicted to be non-polar, approximately neutral, or slightly basic $(7.1-8.71)$ and with a non-cytoplasmic location, similarly to most of the other $C$ proteins found for the sunrhaviruses and tupaviruses, with the notable exception of Klamath virus (KLAV) and TUPV (Supplementary Materials, Table S4). Another common additional ORF (216-234 nt, $71-77 \mathrm{aa}$ ) to all the seven viruses was found between the $M$ and $G$ genes, corresponding to the small hydrophobic $(\mathrm{SH})$ protein previously also observed in the tupaviruses and the previously unclassified SUNV, HDV, WCV, and GARV. Here, again, the identity of the amino-acid sequences of this SH protein was variable but higher between the seven newly described bird-related viruses and GARV $(32.4-85.9 \%)$ than after comparison to the other 
sunrhaviruses, namely HDV, SUNV, and WCB (20.2-28.2\%), or to the tupaviruses Durham virus (DURV), KLAV, and TUPV (13.8-23.3\%) (Supplementary Materials, Figure S3 and Table S3B). The SH proteins of the remaining sunrhaviruses Dillard's Draw virus (DDV), Kwatta virus (KWAV), and Oak Vale virus (OVRV) were clearly distinct from the other $\mathrm{SH}$ proteins (Supplementary Materials, Figure S3 and Table S3B). The topology of this acidic (4.65-6.55) and hydrophobic protein was similar for the bird-related viruses, with a signal peptide (13-20 aa), followed by an extracellular region (9 or $15 \mathrm{aa}$ ), a transmembrane part (18-27 aa) with two amino acid helices, and a cytoplasmic domain (22 or 28 aa) at the C-term (Supplementary Materials, Table S5). This topology is also observed with SUNV, DDV, and HDV. Lastly, BBOV, KOLV, and BEAV exhibited a putative ORF within the N gene, whereas from one to three additional ORFs were found in the G gene for SJAV and KOLV or for BBOV, respectively. None of these additional ORFs exhibited similarities with other known proteins after a BLASTp analysis of non-redundant protein sequences or Uniprot databases, with default parameters.

The transcription initiation (TI) signal was highly conserved among the five canonical genes, with the AACA sequence motif (Supplementary Materials, Figure S4). The consensus sequence of the transcription termination (TTP) for the canonical genes was TGA ${ }_{7}$, except for the $\mathrm{M}$ gene of KOLV and OUAV, which had TGA 6 and TGA ${ }_{8}$, respectively, or for the $\mathrm{L}$ gene of SAJV, which exhibited the CGA 7 motif. These conserved TI and TTP signal sequences were observed for only one of the putative accessory genes $(\mathrm{SH})$ and for all of the seven bird rhabdoviruses. Surprisingly, the TTP sequence of the SH gene for the virus OUAV was found after the TI sequence of the next gene (G gene) (Supplementary Materials, Figure S4). Intriguingly, a TTP signal sequence was observed just before the TI signal sequence of the N gene for $\mathrm{KOLV}$, suggesting the upstream presence of an additional ORF.

\subsection{Phylogenetic Analysis of the Bird-Related Rhabdoviruses}

A first maximum likelihood phylogenetic analysis was conducted on the complete amino acid sequences of the $\mathrm{L}$ protein of the seven bird-related rhabdoviruses, in addition to the 229 representative members of the Rhabdoviridae family available in GenBank (Figure 2, and Supplementary Materials, Table S2). Based on this phylogeny, the seven birdrelated rhabdoviruses clustered together into the genus Sunrhavirus with high bootstrap supports. Within this genus, they were strongly associated with GARV, one of the other bird-related rhabdoviruses found in this genus, whereas the other bird-related rhabdovirus SUNV was found to be more genetically distant.

A second phylogenetic analysis was conducted on the genus Sunrhavirus, based on the concatenated nucleotide sequences of the five canonical genes (N, P, M, G, and L) for the seven different members already associated with this genus, in addition to the seven new sequences (Figure 3). Interestingly, all of these seven bird-related rhabdoviruses clustered into the same phylogroup, identified as Clade III, with GARV, which was found also in birds in Africa, and more precisely in the Central African Republic (Figure 3) [1]. The other unique bird-related rhabdovirus of the genus not related to Clade III was SUNV, which clustered with two Australian insects rhabdoviruses into another clade (Clade II) [17]. However, we observed a close genetic relationship between these two clades (Figure 3). Within Clade III, all the viruses appeared to be genetically relatively distant from each other, suggesting that they could be considered to be individual species. 


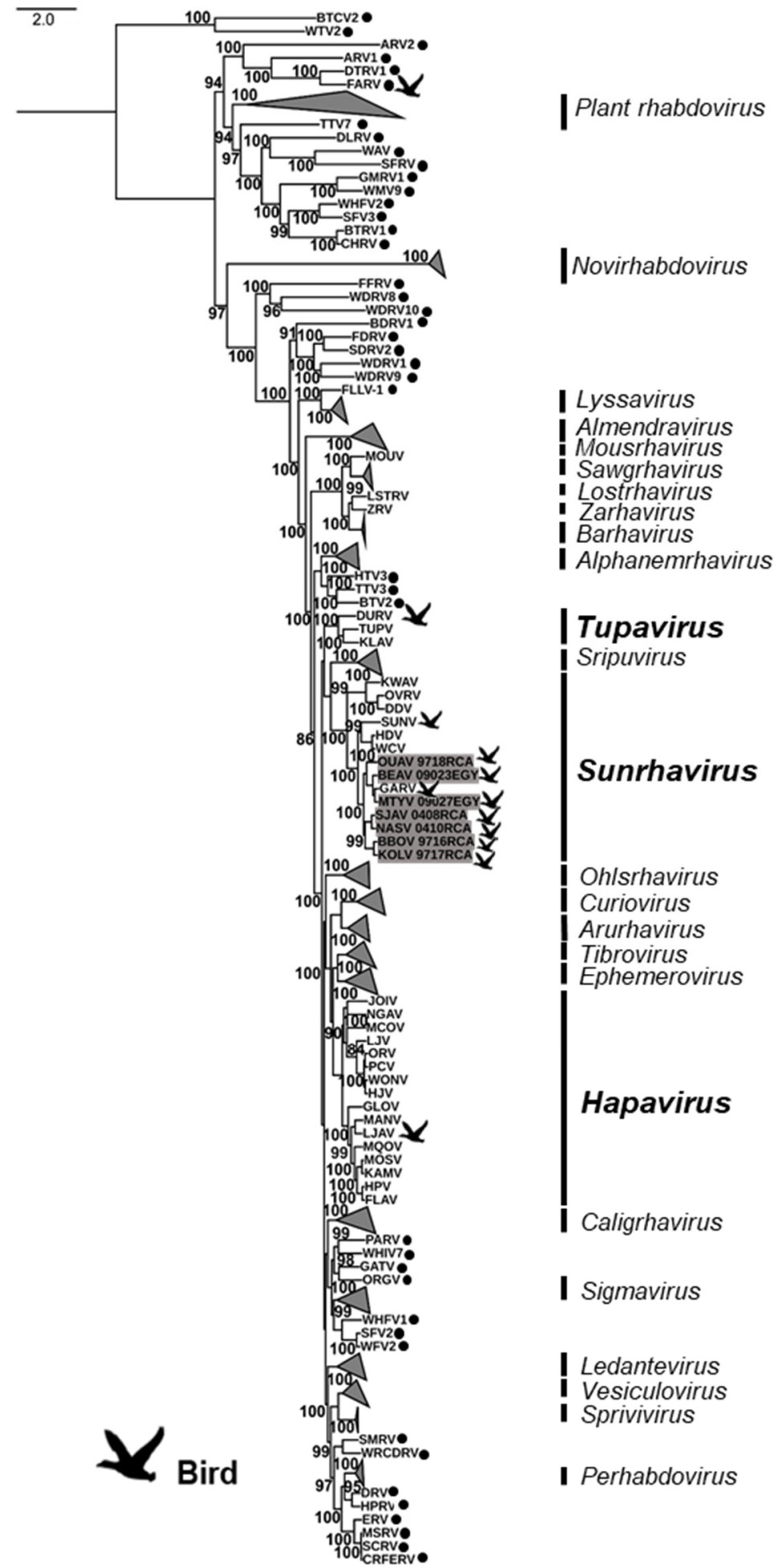

Figure 2. Phylogenetic classification of the seven bird sunrhaviruses. A maximum likelihood phylogenetic tree was made using IQ-TREE1.6.10, on the full amino acid sequence of the L protein, including seven bird-related sunrhaviruses and 229 other rhabdoviruses previously reported on GenBank, using the LG + G + L + F model with 10,000 ultrafast bootstraps. The rhabdovirus genera that were not related to birds were collapsed in the phylogenetic tree. Bird-related rhabdoviruses are indicated by a dedicated symbol, and the bird-related genera are shown in bold. Unclassified rhabdoviruses are indicated by black dots. The bird-related rhabdoviruses described in this study are highlighted in gray. All bootstrap proportion values (BSP) $>80 \%$ are specified. The scale bar indicates nucleotide substitutions per site. 


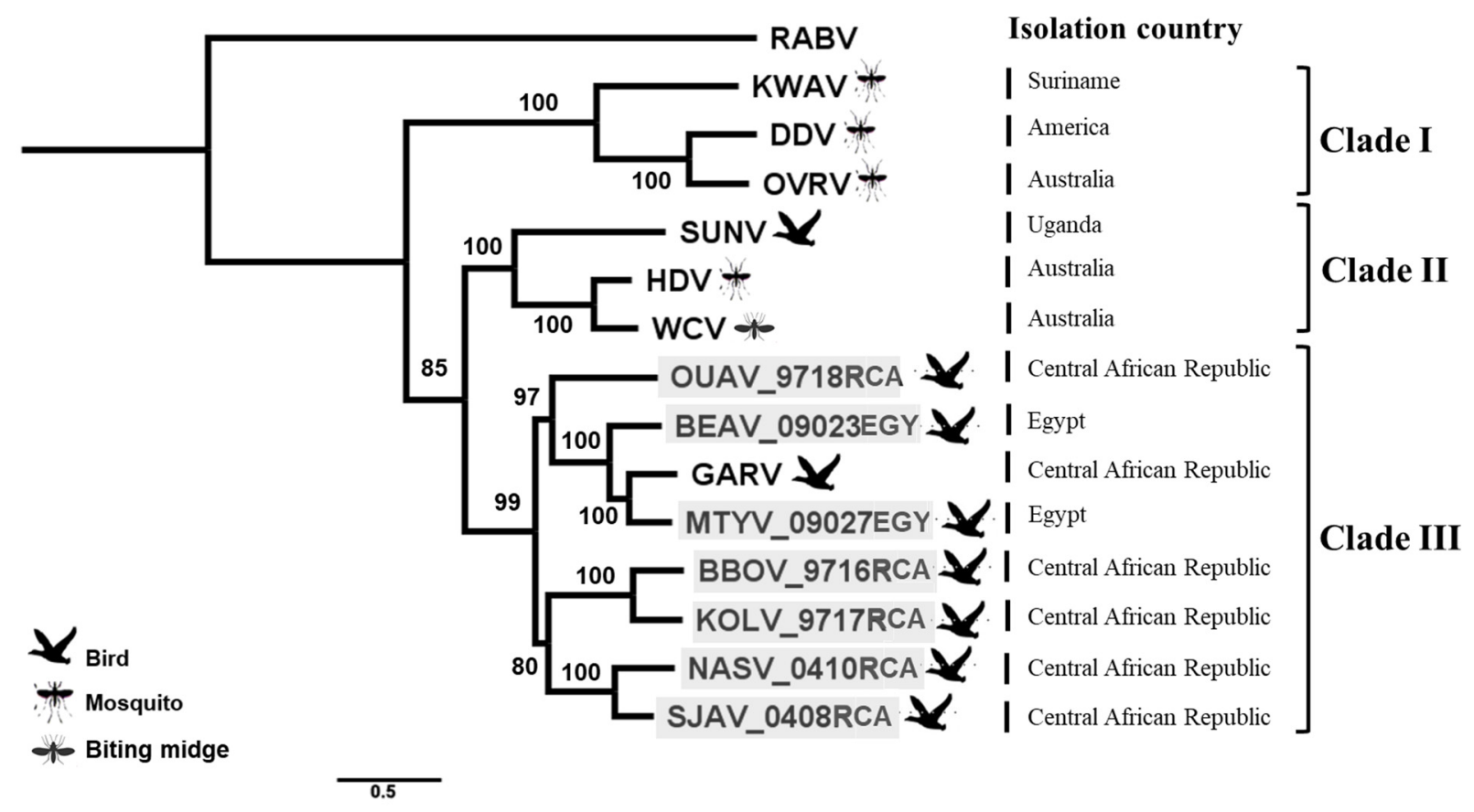

Figure 3. Phylogenetic classification of all members of the genus Sunrhavirus, including the seven newly described birdrelated sunrhaviruses. A maximum likelihood phylogenetic tree was made with PhyML 3.0 on the nucleotide concatenated ORFs (N-P-M-G-L), using the GTR + G + I model and with 1000 bootstrap replicates. The main animal reservoirs for each virus are indicated by specific cartoons, and the seven bird sunrhaviruses described in this study are highlighted in gray. The isolation country for each virus is presented in the right of the illustration. All bootstrap proportion values (BSP) $>80 \%$ are specified. The scale bar indicates nucleotide substitutions per site. The classical rabies virus (RABV) was included as outlier in the phylogenetic analysis.

\subsection{Genetic Diversity of the Bird-Related Rhabdoviruses}

In addition to the phylogenetic analysis, we compared the canonical ORFs $(\mathrm{N}, \mathrm{P}, \mathrm{M}$, $\mathrm{G}$, and $\mathrm{L}$ ) of the seven bird-related rhabdoviruses with the other members within the genus Sunrhavirus, at the individual level (complete amino acid sequences for each) or after concatenation (concatenated complete nucleotide sequences) (Table 3, and Supplementary Materials, Table S6). The close genetic relationship between these seven bird-related rhabdoviruses exhibited by the phylogeny was confirmed at the amino acid and nucleotide identity level of these canonical ORFs. These identity analyses also confirmed that these viruses were putative individual species. Indeed, they exhibited a high level of diversity between these viruses and the other members of genus Sunrhavirus, with nucleotide identities for the concatenated sequences ranging from $41 \%$ to $71.9 \%$ among the Sunrhavirus genus, and from $55.5 \%$ to $71.9 \%$ among the seven bird-related rhabdoviruses (Table 3).

At the individual ORF level, the $\mathrm{N}$ and $\mathrm{L}$ proteins were the most conserved among the member of the Sunrhavirus genus, with amino acid identities ranging from $23.8 \%$ to $86.6 \%$ and $38.0 \%$ to $85.2 \%$, respectively (Supplementary Materials, Table S6). Within the seven newly described bird-related rhabdoviruses, the amino acid identities ranged from $45.3 \%$ to $81 \%$ and $58.9 \%$ to $83.1 \%$ for the $\mathrm{N}$ and the L proteins, respectively. The level of identity for the amino acid sequences was lower for the other viral proteins among sunrhaviruses, ranging from $5.7 \%$ to $71.1 \%, 7.1 \%$ to $79.7 \%$, and $20.3 \%$ to $75.5 \%$ for the $\mathrm{P}$, $\mathrm{M}$, and $\mathrm{G}$ proteins, respectively (Supplementary Materials, Table S6). For the seven new bird-related rhabdoviruses, identities were $18.6-68.3 \%, 23.6-66.4 \%$, and $36.1-72.9 \%$ for the seven bird-related rhabdoviruses for the $\mathrm{P}, \mathrm{M}$, and $\mathrm{G}$ proteins, respectively. Altogether, these results indicated that these seven bird-related rhabdoviruses represent new virus species within the Sunrhavirus genus. 
Table 3. Nucleotide identities of concatenated canonical ORFs (N, P, M, G, and L) of members of the Sunrhavirus genus. Identities were calculated through pairwise deletion using MEGA (version 7.0). Newly described bird-related rhabdoviruses are indicated in bold.

\begin{tabular}{|c|c|c|c|c|c|c|c|c|c|c|c|c|c|c|}
\hline & $\begin{array}{c}\text { SJAV } \\
\text { 0408RCA }\end{array}$ & $\begin{array}{c}\text { NASV } \\
\text { 0410RCA }\end{array}$ & $\begin{array}{c}\text { BBOV } \\
\text { 9716RCA }\end{array}$ & $\begin{array}{c}\text { KOLV } \\
\text { 9717RCA }\end{array}$ & $\begin{array}{c}\text { OUAV } \\
\text { 9718RCA }\end{array}$ & $\begin{array}{c}\text { BEAV } \\
\text { 09023EGY }\end{array}$ & $\begin{array}{c}\text { MTYV } \\
\text { 09027EGY }\end{array}$ & GARV & HDV & WCV & SUNV & DDV & OVRV & KWAV \\
\hline \multicolumn{15}{|l|}{$\begin{array}{c}\text { SJAV } \\
\text { 0408RCA }\end{array}$} \\
\hline $\begin{array}{l}\text { NASV } \\
\text { 0410RCA }\end{array}$ & 71.9 & & & & & & & & & & & & & \\
\hline $\begin{array}{l}\text { BBOV } \\
\text { 9716RCA }\end{array}$ & 57.9 & 56.7 & & & & & & & & & & & & \\
\hline $\begin{array}{l}\text { KOLV } \\
\text { 9717RCA }\end{array}$ & 57.9 & 56.2 & 71.3 & & & & & & & & & & & \\
\hline $\begin{array}{l}\text { OUAV } \\
\text { 9718RCA }\end{array}$ & 58.4 & 56.8 & 56 & 55.7 & & & & & & & & & & \\
\hline $\begin{array}{l}\text { BEAV } \\
\text { 09023EGY }\end{array}$ & 57.8 & 56.3 & 56.1 & 55.5 & 58.4 & & & & & & & & & \\
\hline $\begin{array}{l}\text { MTYV } \\
\text { 09027EGY }\end{array}$ & 58.2 & 56.7 & 56.4 & 55.8 & 58.8 & 70.1 & & & & & & & & \\
\hline GARV & 58.2 & 56.5 & 55.5 & 55.7 & 59 & 69.2 & 73.2 & & & & & & & \\
\hline HDV & 51.7 & 50 & 50.8 & 50.5 & 51.5 & 51.5 & 51 & 51.1 & & & & & & \\
\hline WCV & 50.6 & 48.9 & 49.8 & 49.4 & 50.6 & 51.3 & 50.6 & 50.5 & 74.8 & & & & & \\
\hline SUNV & 48.9 & 48.1 & 47.5 & 47.2 & 48.6 & 48.8 & 47.9 & 48.2 & 54 & 53.8 & & & & \\
\hline DDV & 42.4 & 41.6 & 42.3 & 41.8 & 42.4 & 42.4 & 42.3 & 42.1 & 43.4 & 42.5 & 41.5 & & & \\
\hline OVRV & 41 & 40.5 & 41 & 41.5 & 41 & 41.8 & 41.6 & 41.4 & 42.4 & 41.9 & 40.8 & 65.2 & & \\
\hline KWAV & 42.3 & 41.4 & 41.9 & 41.7 & 41.9 & 41.6 & 41.8 & 42 & 42.7 & 42.1 & 41.2 & 52.1 & 51.9 & \\
\hline
\end{tabular}

\section{Discussion}

To date, only 12 rhabdoviruses have been identified in birds. Among them, all except SUNV were collected from wild birds, the latter being isolated from chicken [12]. Two of them originated from the USA, namely DURV and FARV. The other bird-related rhabdoviruses were isolated in Africa and were collected in Uganda (SUNV), Egypt (BEAV and MTYV), and the Central African Republic (BBOV, GARV, KOLV, LJAV, NASV, OUAV, and SJAV) [5,15]. Up to now, complete or nearly complete genome data was available for only four of them, including DURV, which belongs to Tupavirus genus, GARV, which is a member of the Sunrhavirus genus, LJAV, which clustered with Hapavirus genus, and FARV, which remains unassigned $[5,15]$. For all of the seven other viruses, only partial $\mathrm{N}$ or L gene sequences were available, and they were initially classified in the group Sandjimba $[1,12,14,16-19]$. In this study, we have enlarged our knowledge about birdrelated rhabdoviruses with the determination of the nearly complete genome of these seven other isolates using NGS, which were isolated in various wild birds in Egypt and the Central African Republic of Africa from the 1960s to the 1970s [5,15].

Phylogenetic analysis conducted on the genome sequences demonstrated that they could potentially be all assigned to the newly created Sunrhavirus genus, which was set up by the latest update of the International Committee on Taxonomy of Viruses in 2020 (ICTV: https:/ / talk.ictvonline.org/, accessed on 25 September 2021). Seven virus species were associated with this genus, including the two bird-related viruses GARV and SUNV, and five viruses isolated in insects. According to the criteria of the ICTV for species demarcation among the sunrhaviruses, new species need to exhibit a minimum amino acid sequence divergence of $10 \%, 15 \%$, and $10 \%$ for the N, G, and L proteins, respectively. Based on these criteria, all of the seven newly described bird-related rhabdoviruses meet these requirements, with a minimum amino acid sequence divergence of $13.4 \%, 26.5 \%$, and $16.9 \%$ for the N, G, and L proteins, respectively (Supplementary Materials, Table S6). For these bird-related rhabdoviruses, we therefore propose the tentative name species Sunrhavirus sandjimba for SJAV, Sunrhavirus nasoule for NASV, Sunrhavirus bimbo for BBOV, Sunrhavirus kolongo for KOLV, Sunrhavirus ouango for OUAV, Sunrhavirus Alexandria for BEAV, and Sunrhavirus matariya for MTYV, according to the binomial nomenclature recently adopted for viruses by the ICTV [33]. 
In addition to the similar length and genetic relatedness of each viral genome between these bird-related rhabdoviruses and the other members of the genus Sunrhavirus, other common features were also observed, with the presence of the two accessory genes $\mathrm{C}$ (within the P gene) and SH (between the $\mathrm{M}$ and the $\mathrm{G}$ genes). Similar $\mathrm{C}$ proteins can be observed in rhabdovirus genera other than Sunrhavirus genus, such as Vesiculovirus [34], Lyssavirus [35], Ephemerovius (with the $\mathrm{P}^{\prime}$ protein) [36], Tupavirus, and Hapavirus genera [1], or even in other virus families, such as the Paramyxoviridae family. These $\mathrm{C}$ proteins, which expression could occur by leaky ribosomal scanning, are generally considered as highly basic. However, this feature was not observed in the case of the newly described bird-related rhaboviruses. Their precise functions remain unknown, although it has been speculated that they could enhance transcriptional activity or act in viral pathogenesis [34]. The small hydrophobic proteins $\mathrm{SH}$ are encoded as additional transcriptional units between the $\mathrm{M}$ and the $\mathrm{G}$ genes for all the sunrhaviruses described so far $[1,12,17,19,37]$. In addition, similar proteins (coded also as additional transcriptional units between the $M$ and the $G$ genes) have been described for the members of the Tupavirus genus, including DURV [11], KLAV [1], and TUPV [38], and more distantly genetically for the members of Sripuvirus genus [1]. These proteins are lacking predicted transmembrane domains and presented a highly hydrophilic N-terminal domain, but their function remains unknown $[1,3]$.

Based either on the nucleotide concatenated genome sequences or on the complete amino acid polymerase sequences, all of the seven bird-related rhabdoviruses clustered with GARV in a distinct group, identified here as Clade III, within the genus Sunrhavirus. This phylogroup encompasses exclusively viruses from wild African birds (in the Central African Republic and Egypt) [1,5,15]. Two other phylogroups were also observed in this genus, with the phylogroup Clade II closely related to Clade III and encompassing two viruses (HDV and WCV) which were isolated from insects in Australia, in addition to SUNV, which was isolated in Uganda from a chicken [12]. Lastly, the phylogroup Clade I included three sunrhaviruses found in insects of American and Australian origin [1,19,37]. All together, these results demonstrate the high genetic diversity within the Sunrhavirus genus, which potentially includes now 14 members from three main geographical areas, namely Africa, America, and Australia.

The fact that the members of the Sunrhavirus genus were isolated from insects (mosquitoes with Culex species and biting midges with Culicoides species) or birds is intriguing, and raises the question about a potential arboviral epidemiological cycle in birds, similar to other bird-related arboviruses, such as West Nile virus [39] or Usutu virus [40]. This is supported by the presence of some of these viruses isolated in the blood of these animals, and that mosquitoes such as Culex species feed on these animals [41]. However, studies conducted on SUNV failed to demonstrate virus replication in most of the invertebrate cell lines tested or virus dissemination/infection in the challenged mosquitoes [12]. Similarly, the bird-associated DURV of the Tupavius genus was not able to replicate in the insect cell line tested [11]. Further investigations are therefore necessary in order to assess the infection capacities in arthropods of the sunrhaviruses, especially those belonging to the phylogenetic Clade III.

Conversely, it remains also to be elucidated as to what extent these sunrhaviruses could be specifically associated with birds as vertebrate hosts, and what could be the pathologies induced after infection. Indeed, all of the bird-related sunrhaviruses were isolated from animals during nonspecific epidemiological surveillance of arboviruses, without information related to disease or potential clinical signs associated with the infected animals. Only the tupavirus DURV was suspected to be associated with disease in birds, being isolated from a moribund American coot (Fulica Americana) that exhibited neurological signs in North Carolina [11]. A first study aiming to evaluate the circulation of HDV and WCV sunrhaviruses in various vertebrates in Australia failed to find serological evidence of infection in wild or domestic birds [17]. However, additional studies, including seroprevalence analysis, will be necessary in order to extend the search for rhabdoviruses in birds in Africa, America, and Australia, but also in other unexplored regions, such as 
Asia or Europe. Moreover, the possibility of the infection of other vertebrates, such as humans or other mammals, must be considered and evaluated, especially since it has been demonstrated that different mammalian cells can support the replication of some of these viruses, such as SUNV, HDV, OVRV, KWA, and WCV [12,17,19].

Lastly, it is important to underline that the seven bird-related rhabdoviruses described here are part of a large and unique historical collection of arboviruses which were isolated during field campaigns carried out in the 1960s and 1970s on wildlife, particularly in Africa, and of which some of the isolates have yet to be characterized. Thus, complementary studies would make it possible to assess whether these viruses are still circulating and, if so, to investigate their genetic evolution, taking into account changes that may have affected environmental factors or their hosts.

Supplementary Materials: The following are available online at https:/ /www.mdpi.com/article/10 $.3390 / \mathrm{v} 13112168 / \mathrm{s} 1$, Figure S1: Reads coverage of the genome sequences of the seven bird-related sunrhaviruses, Figure S2: Alignment and genetic comparison of the $C$ proteins from sunrhaviruses and tupaviruses, Figure S3: Alignment and genetic comparison of the $\mathrm{SH}$ proteins from sunrhaviruses and tupaviruses, Figure S4: Description of the transcription initiation (TI) and the transcription termination (TTP) signal sequences of the genes of the seven bird-related sunrhaviruses, and their positions related to the ATG of the associated ORF, Table S1: Description of the primers specifically designed to fulfil gaps in the genome sequences generated after NGS sequencing, Table S2: Details of the 236 rhabdoviruses included in the phylogenetic analysis, Table S3: Amino acid identities of $C$ (Table S3A) and SH (Table S3B) proteins of sunrhaviruses and tupaviruses, Table S4: Description of the $\mathrm{C}$ proteins from sunrhaviruses and tupaviruses, Table S5: Description of the $\mathrm{SH}$ proteins from sunrhaviruses and tupaviruses, Table S6: Amino acid identities of each canonical proteins (N, P, M, $\mathrm{G}$, and L) of sunrhaviruses.

Author Contributions: Conceptualization, D.-S.L., M.G. and L.D.; methodology, D.-S.L. and L.D.; validation, D.-S.L. and L.D.; formal analysis, D.-S.L. and L.D.; data curation, Z.-J.Z., D.-S.L. and L.D.; resources, M.G. and H.B.; writing-original draft preparation, D.-S.L. and L.D.; writing—review and editing, D.-S.L. and L.D.; supervision, L.D. and Z.-L.S.; project administration, L.D., H.B. and Z.-L.S.; funding acquisition, L.D., H.B., X.-Y.G. and Z.-L.S. All authors have read and agreed to the published version of the manuscript.

Funding: This work was jointly funded by Campus France and China Scholarship Council (L.D.) through the PHC Cai Yuanpei 2016 program under grant number 36724VF. This study also received funding from the Scientific and technological basis special project (2013FY113500) and Institut Pasteur, Paris.

Institutional Review Board Statement: Not applicable.

Informed Consent Statement: Not applicable.

Data Availability Statement: The data presented in this study are available in the present article and in supplementary material. Complete genome sequences were deposited in GenBank under the accession numbers MW491754-MW491760.

Acknowledgments: We thank the sequencing facilities of the "Plate-forme de microbiologie mutalisée (P2M)" of Institut Pasteur, Paris, France for technical assistance with NGS sequencing. We would also thank Corinne Maufrais for her continuous assistance in NGS analysis. Lastly, we would like to thank Peter Walker for his advice with the binomial nomenclature selection of the bird-related rhabdoviruses and their submission to the ICTV.

Conflicts of Interest: The authors declare no conflict of interest. The funders had no role in the design of the study; in the collection, analyses, or interpretation of data; in the writing of the manuscript, or in the decision to publish the results.

\section{References}

1. Walker, P.J.; Firth, C.; Widen, S.G.; Blasdell, K.R.; Guzman, H.; Wood, T.G.; Paradkar, P.N.; Holmes, E.C.; Tesh, R.B.; Vasilakis, N. Evolution of Genome Size and Complexity in the Rhabdoviridae. PLoS Pathog. 2015, 11, e1004664. [CrossRef]

2. Kuhn, J.H.; Adkins, S.; Alioto, D.; Alkhovsky, S.V.; Amarasinghe, G.K.; Anthony, S.J.; Avšič-Županc, T.; Ayllón, M.A.; Bahl, J.; Balkema-Buschmann, A.; et al. 2020 Taxonomic Update for Phylum Negarnaviricota (Riboviria: Orthornavirae), Including the Large Orders Bunyavirales and Mononegavirales. Arch. Virol. 2020, 50, 3023-3072. [CrossRef] 
3. Walker, P.J.; Dietzgen, R.G.; Joubert, D.A.; Blasdell, K.R. Rhabdovirus Accessory Genes. Virus Res. 2011, 162, 110-125. [CrossRef]

4. Walker, P.J.; Blasdell, K.R.; Calisher, C.H.; Dietzgen, R.G.; Kondo, H.; Kurath, G.; Longdon, B.; Stone, D.M.; Tesh, R.B.; Tordo, N.; et al. ICTV Virus Taxonomy Profile: Rhabdoviridae. J. Gen. Virol. 2018, 99, 447-448. [CrossRef] [PubMed]

5. Calisher, C.H.; Karabatsos, N.; Zeller, H.; Digoutte, J.-P.; Tesh, R.B.; Shope, R.E.; da Rosa, A.P.A.T.; George, T.D.S. Antigenic Relationships among Rhabdoviruses from Vertebrates and Hematophagous Arthropods. Intervirology 1989, 30, 241-257. [CrossRef]

6. Clark, G.G.; Taylor, D.E.; Crabbs, C.L.; Calisher, C.H.; Bowen, R.A.; Tesh, R.B.; Canestorp, K.M. Malpais Spring Virus: A New Vesiculovirus from Mosquitoes Collected in New Mexico and Evidence of Infected Indigenous and Exotic Ungulates. Am. J. Trop. Med. Hyg. 1988, 39, 586-592. [CrossRef] [PubMed]

7. Kurz, W.; Gelderblom, H.; Flügel, R.M.; Darai, G. Isolation and Characterization of a Tupaia Rhabdovirus. Intervirology 1986, 25, 88-96. [CrossRef]

8. Bourhy, H.; Sureau, P.; Tordo, N. From Rabies to Rabies-Related Viruses. Vet. Microbiol. 1990, 23, 115-128. [CrossRef]

9. Gibbs, A.J. Viral Taxonomy Needs a Spring Clean; Its Exploration Era Is Over. Virol. J. 2013, 10, 254. [CrossRef] [PubMed]

10. Simmonds, P.; Adams, M.J.; Benkő, M.; Breitbart, M.; Brister, J.R.; Carstens, E.B.; Davison, A.J.; Delwart, E.; Gorbalenya, A.E.; Harrach, B.; et al. Consensus statement: Virus taxonomy in the age of metagenomics. Nat. Rev. Microbiol. 2017, 15, 161-168. [CrossRef]

11. Allison, A.B.; Palacios, G.; Travassos da Rosa, A.; Popov, V.L.; Lu, L.; Xiao, S.Y.; DeToy, K.; Briese, T.; Lipkin, W.I.; Keel, M.K.; et al. Characterization of Durham Virus, a Novel Rhabdovirus That Encodes Both a C and SH Protein. Virus Res. 2011, 155, 112-122. [CrossRef] [PubMed]

12. Ledermann, J.P.; Zeidner, N.; Borland, E.M.; Mutebi, J.-P.; Lanciotti, R.S.; Miller, B.R.; Lutwama, J.J.; Tendo, J.M.; Andama, V.; Powers, A.M. Sunguru Virus: A Novel Virus in the Family Rhabdoviridae Isolated from a Chicken in North-Western Uganda. J. Gen. Virol. 2014, 95, 1436-1443. [CrossRef]

13. Palacios, G.; Forrester, N.L.; Savji, N.; Travassos da Rosa, A.P.A.; Guzman, H.; DeToy, K.; Popov, V.L.; Walker, P.J.; Lipkin, W.; Vasilakis, N.; et al. Characterization of Farmington Virus, a Novel Virus from Birds That Is Distantly Related to Members of the Family Rhabdoviridae. Virol. J. 2013, 10, 219. [CrossRef] [PubMed]

14. de Haas, R.A.; Jonkers, A.H.; Heinemann, D.W. Kwatta Virus, a New Agent Isolated from Culex Mosquitoes in Surinam *. Am. J. Trop. Med. Hyg. 1966, 15, 954-957. [CrossRef]

15. Mekki, A.A.E.; Nieuwenhuysen, P.; van der Groen, G.; Pattyn, S.R. Characterization of Some Ungrouped Viruses. Trans. R. Soc. Trop. Med. Hyg. 1981, 75, 799-806. [CrossRef]

16. Dacheux, L.; Berthet, N.; Dissard, G.; Holmes, E.C.; Delmas, O.; Larrous, F.; Guigon, G.; Dickinson, P.; Faye, O.; Sall, A.A.; et al. Application of Broad-Spectrum Resequencing Microarray for Genotyping Rhabdoviruses. J. Virol. 2010, 84, 9557-9574. [CrossRef]

17. McAllister, J.; Gauci, P.J.; Mitchell, I.R.; Boyle, D.B.; Bulach, D.M.; Weir, R.P.; Melville, L.F.; Davis, S.S.; Gubala, A.J. Genomic Characterisation of Almpiwar Virus, Harrison Dam Virus and Walkabout Creek Virus; Three Novel Rhabdoviruses from Northern Australia. Virol. Rep. 2014, 3-4, 1-17. [CrossRef]

18. Kuzmin, I.V. Phylogenetic Relationships of Seven Previously Unclassified Viruses within the Family Rhabdoviridae Using Partial Nucleoprotein Gene Sequences. J. Gen. Virol. 2006, 87, 2323-2331. [CrossRef] [PubMed]

19. Quan, P.-L.; Williams, D.T.; Johansen, C.A.; Jain, K.; Petrosov, A.; Diviney, S.M.; Tashmukhamedova, A.; Hutchison, S.K.; Tesh, R.B.; Mackenzie, J.S.; et al. Genetic Characterization of K13965, a Strain of Oak Vale Virus from Western Australia. Virus Res. 2011, 160, 206-213. [CrossRef]

20. Tesh, R.B.; Travassos Da Rosa, A.P.A.; Travassos Da Rosa, J.S.Y. Antigenic Relationship Among Rhabdoviruses Infecting Terrestrial Vertebrates. J. Gen. Virol. 1983, 64, 169-176. [CrossRef]

21. Pallandre, L.; Luo, D.; Feuvrier, C.; Lieffrig, F.; Pozet, F.; Dacheux, L.; Bigarré, L. Revisiting the Classification of Percid Perhabdoviruses Using New Full-Length Genomes. Viruses 2020, 12, 649. [CrossRef] [PubMed]

22. Luo, D.-S.; Li, B.; Shen, X.-R.; Jiang, R.-D.; Zhu, Y.; Wu, J.; Fan, Y.; Bourhy, H.; Hu, B.; Ge, X.-Y.; et al. Characterization of Novel Rhabdoviruses in Chinese Bats. Viruses 2021, 13, 64. [CrossRef]

23. Dacheux, L.; Dommergues, L.; Chouanibou, Y.; Doméon, L.; Schuler, C.; Bonas, S.; Luo, D.; Maufrais, C.; Cetre-Sossah, C.; Cardinale, E.; et al. Co-circulation and Characterization of Novel African Arboviruses (Genus Ephemerovirus) in Cattle, Mayotte Island, Indian Ocean, 2017. Transbound. Emerg. Dis. 2019, 66, 2601-2604. [CrossRef]

24. Mareuil, F.; Doppelt-Azeroual, O.; Ménager, H. A Public Galaxy Platform at Pasteur Used as an Execution Engine for Web Services. F1000Research 2017, 6, 1030. [CrossRef]

25. Milne, I.; Stephen, G.; Bayer, M.; Cock, P.J.; Pritchard, L.; Cardle, L.; Shaw, P.D.; Marshall, D. Using Tablet for Visual Exploration of Second-Generation Sequencing Data. Brief. Bioinform. 2012, 14, 193-202. [CrossRef]

26. Larkin, M.A.; Blackshields, G.; Brown, N.P.; Chenna, R.; McGettigan, P.A.; McWilliam, H.; Valentin, F.; Wallace, I.M.; Wilm, A.; Lopez, R.; et al. Clustal W and Clustal X Version 2.0. Bioinformatics 2007, 23, 2947-2948. [CrossRef]

27. Sievers, F.; Wilm, A.; Dineen, D.; Gibson, T.J.; Karplus, K.; Li, W.; Lopez, R.; McWilliam, H.; Remmert, M.; Söding, J.; et al. Fast, Scalable Generation of High-quality Protein Multiple Sequence Alignments Using Clustal Omega. Mol. Syst. Biol. $2011,7,539$. [CrossRef] [PubMed]

28. Nguyen, L.-T.; Schmidt, H.A.; von Haeseler, A.; Minh, B.Q. IQ-TREE: A Fast and Effective Stochastic Algorithm for Estimating Maximum-Likelihood Phylogenies. Mol. Biol. Evol. 2015, 32, 268-274. [CrossRef] [PubMed] 
29. Guindon, S.; Dufayard, J.F.; Lefort, V.; Anisimova, M.; Hordijk, W.; Gascuel, O. New Algorithms and Methods to Estimate Maximum-Likelihood Phylogenies: Assessing the Performance of PhyML 3.0. Syst. Biol. 2010, 59, 307-321. [CrossRef]

30. Kumar, S.; Stecher, G.; Tamura, K. MEGA7: Molecular Evolutionary Genetics Analysis Version 7.0 for Bigger Datasets. Mol. Biol. Evol. 2016, 33, 1870-1874. [CrossRef]

31. Gasteiger, E.; Hoogland, C.; Gattiker, A.; Duvaud, S.; Wilkins, M.R.; Appel, R.D.; Bairoch, A. Protein Identification and Analysis Tools on the ExPASy Server. In The Proteomics Protocols Handbook; Walker, J.M., Ed.; Humana Press Inc.: Totowa, NJ, USA, 2005; pp. 571-607. [CrossRef]

32. Kall, L.; Krogh, A.; Sonnhammer, E.L.L. Advantages of Combined Transmembrane Topology and Signal Peptide Prediction-The Phobius Web Server. Nucleic Acids Res. 2007, 35, W429-W432. [CrossRef]

33. Walker, P.J.; Siddell, S.G.; Lefkowitz, E.J.; Mushegian, A.R.; Adriaenssens, E.M.; Alfenas-Zerbini, P.; Davison, A.J.; Dempsey, D.M.; Dutilh, B.E.; García, M.L.; et al. Changes to Virus Taxonomy and to the International Code of Virus Classification and Nomenclature Ratified by the International Committee on Taxonomy of Viruses (2021). Arch. Virol. 2021, 166, $2633-2648$. [CrossRef] [PubMed]

34. Peluso, R.W.; Richardson, J.C.; Talon, J.; Lock, M. Identification of a Set of Proteins ( $C^{\prime}$ and C) Encoded by the Bicistronic P Gene of the Indiana Serotype of Vesicular Stomatitis Virus and Analysis of Their Effect on Transcription by the Viral RNA Polymerase. Virology 1996, 218, 335-342. [CrossRef]

35. Nadin-Davis, S.A.; Abdel-Malik, M.; Armstrong, J.; Wandeler, A.I. Lyssavirus P Gene Characterisation Provides Insights into the Phylogeny of the Genus and Identifies Structural Similarities and Diversity within the Encoded Phosphoprotein. Virology 2002, 298, 286-305. [CrossRef]

36. Walker, P.J. Bovine Ephemeral Fever in Australia and the World. In The World of Rhabdoviruses; Fu, Z.F., Ed.; Springer: Berlin/Heidelberg, Germany, 2005; Volume 292, pp. 57-80.

37. Reeves, W.K.; Miller, M.M.; Gruner, W.E. Two Rhabdoviridae: Dillard's Draw Virus, a Putative New Virus, and Merida Virus from Culex Tarsalis (Diptera: Culicidae) in New Mexico, USA. Acta Virol. 2018, 62, 326-329. [CrossRef] [PubMed]

38. Springfeld, C.; Darai, G.; Cattaneo, R. Characterization of the Tupaia Rhabdovirus Genome Reveals a Long Open Reading Frame Overlapping with P and a Novel Gene Encoding a Small Hydrophobic Protein. J. Virol. 2005, 79, 6781-6790. [CrossRef] [PubMed]

39. Montecino-Latorre, D.; Barker, C.M. Overwintering of West Nile Virus in a Bird Community with a Communal Crow Roost. Sci. Rep. 2018, 8, 6088. [CrossRef]

40. Vilibic-Cavlek, T.; Petrovic, T.; Savic, V.; Barbic, L.; Tabain, I.; Stevanovic, V.; Klobucar, A.; Mrzljak, A.; Ilic, M.; Bogdanic, M.; et al. Epidemiology of Usutu Virus: The European Scenario. Pathogens 2020, 9, 699. [CrossRef]

41. Farajollahi, A.; Fonseca, D.M.; Kramer, L.D.; Marm Kilpatrick, A. “Bird Biting” Mosquitoes and Human Disease: A Review of the Role of Culex Pipiens Complex Mosquitoes in Epidemiology. Infect. Genet. Evol. 2011, 11, 1577-1585. [CrossRef] 